\title{
EDITORIAL
}

\section{Stereology: a bridge to a better understanding of lung structure and function}

\author{
V. Brusasco* and A.T. Dinh-Xuan ${ }^{\#}$
}

$\mathbf{U}$ nlike solid organs, the lung is a hollow organ that contains, under physiological conditions, an amount of air that is much larger than the total amount of its tissue. This confers to the lung a degree of heterogeneity that is much larger than in any other organ and adds difficulties to the interpretation of physiological measurements, which are in most cases related to the whole system. To overcome these difficulties and to construct suitable models for lung function, a number of studies on the relationships between structure and function have been performed over the last five decades. The major problem in relating lung function measurements to morphological data is the need to gather information on a three-dimensional (3D) structure from two-dimensional (2D) observations. Although data from simple 2D images have been widely used to describe pathological changes in lung parenchyma or airways, their relevance to physiological events occurring in 3D structures is limited.

The key to obtaining valuable 3D morphometric data from 2D measurements is provided by stereology. This method had its foundations lain in 1777 by G. Buffon, who discovered the relationships between geometry and probability [1]. This opened the way for classical model-based stereology, which required an assumption of homogeneity of $3 \mathrm{D}$ structure. Stereology was first applied to medicine in the 1940s and to respiratory systems in 1952 by CAMPBELL and TOMKEIEFF [2], who calculated the internal surface of the lung.

Major advances in lung quantitative morphometry were bestowed by WeIBEL and co-workers [3-6] between the 1960s and 70s. They provided the basic tools for modern designbased stereology. This is particularly suitable for the lung, as it can be applied to structures that are inhomogeneous or cannot be assumed to be homogeneous. Despite this and the subsequent developments made towards obtaining unbiased quantitative data of inhomogeneous structures, such as lung parenchyma and the bronchial tree, stereology has been used less in pulmonary research than in other fields.

In recent years, the European Respiratory Society (ERS) has organised two courses dedicated to quantitative morphology in pulmonary research, followed by a series of articles in one issue of the European Respiratory Review which offered insight into the

*Dept of Internal Medicine, Medical School, University of Genoa, Genoa, Italy. \#Dept of Cardiopulmonary Medicine, Cochin Hospital, University Paris Descartes, Paris, France.

CORRESPONDENCE: V. Brusasco, Dept of Internal Medicine, University of Genoa, Viale Benedetto XV, 6, 16132 Genova, Italy. E-mail: vito.brusasco@unige.it theoretical principles and practical applications of design-based stereology to graduate students and scientists [7-13].

In the February 15th, 2010, issue of the American Journal of Respiratory and Critical Care Medicine, the American Thoracic Society (ATS) and the ERS jointly published an official research policy statement on quantitative assessment of lung structure [14]. This document is the product of a Joint ATS/ERS Task Force formed in response to a number of recent editorials and debates in the leading respiratory journals [15-19] emphasising the need for "minimum standards" in the quantification of lung structure. The aims of this project were, therefore, to critically review the state-of-the-art methods for lung morphometry and provide guidelines for obtaining measurements that are comparable not only for basic and translational research but also for application to noninvasive lung imaging, such as computed tomography, magnetic resonance, and positron emission tomography scanning in vivo.

Some leading journals of other disciplines have established policies demanding [20] or even making mandatory [21] the use of unbiased stereological methods for morphologic analyses. As Editors of the European Respiratory Journal, we do not intend to establish similar strict policies, but we strongly encourage those who are involved in lung function and structure research to take advantage of unbiased methods of stereology whenever possible.

\section{STATEMENT OF INTEREST}

Statements of interest for V. Brusasco and A.T. Dinh-Xuan can be found at www.erj.ersjournals.com/misc/statements.dtl

\section{REFERENCES}

1 Buffon G. Essai d'arithmetique morale. Supplément à l'Histoire Naurelle 1777; 4.

2 Campbell H, Tomkeieff SI. Calculation of the internal surface of a lung. Nature 1952; 170: 116-117.

3 Weibel ER, Gomez DM. Architecture of the human lung. Use of quantitative methods establishes fundamental relations between size and number of lung structures. Science 1962; 137: 577-585.

4 Weibel ER. Morphometry of the Human Lung. Berlin, SpringerVerlag, 1963.

5 Weibel ER. Stereological Methods - Practical Methods for Biological Morphometry. Volumes 1 and 2. New York, Academic Press, 1979.

6 Weibel ER. Morphometry of the human lung: the state of the art after two decades. Bull Physiopathol Respir 1979; 15: 999-1013.

7 Fehrenbach $\mathrm{H}$. There is no rationale to still rely on outdated, biased tools for quantitative morphology in pulmonary research. Eur Respir Rev 2006; 15: 105-106. 
8 Nyengaard JR, Gundersen HJG. Sampling for stereology in lungs. Eur Respir Rev 2006; 15: 107-114.

9 Ochs M. Stereological analysis of acute lung injury. Eur Respir Rev 2006; 15: 115-121.

10 Hyde DM, Miller LA, Schelegle ES, et al. Asthma: a comparison of animal models using stereological methods. Eur Respir Rev 2006; 15: 122-135.

11 Fehrenbach H. Animal models of pulmonary emphysema: a stereologist's perspective. Eur Respir Rev 2006; 15: 136-147.

12 Hsia CCW. Quantitative morphology of compensatory lung growth. Eur Respir Rev 2006; 15: 148-156.

13 Woodruff PG, Innes AL. Quantitative morphology using bronchial biopsies. Eur Respir Rev 2006; 15: 157-161.

14 Hsia CCW, Hyde DM, Ochs M, et al. Standards for quantitative assessment of lung structure: an official research policy statement of the ATS/ERS. Am J Respir Crit Care Med 2010; (In press).
15 Fehrenbach H. Alveolization: does " $\mathrm{A}$ " stand for appropriate morphometry? Eur Respir J 2004; 24: 331-332.

16 Fehrenbach H. Design-based counting. Am J Respir Crit Care Med 2004; 169: 1170-1171.

17 Weibel ER, Parameswaran H, Majumdar A, et al. Morphological quantitation of emphysema: a debate. J Appl Physiol 2006; 100: 1419-1421.

18 Hsia CC. Morphological quantitation of emphysema: a debate. J Appl Physiol 2006; 100: 1422-1423.

19 Weibel ER, Hsia CC, Ochs M. How much is there really? Why stereology is essential in lung morphometry. J Appl Physiol 2006; 102: 459-467.

20 Saper CB. Any way you cut it: a new journal policy for the use of unbiased counting methods. J Comp Neurol 1996; 364: 5.

21 Madsen KM. The art of counting. J Am Soc Nephrol 1999; 10: 11241125. 